\title{
Sustainable Development as the Imperative of the Twenty-First Century; Towards Alternative Approaches on Measuring and Monitoring
}

\author{
Lekë Sokoli \\ University Aleksander Moisiu, Durres-Albania \\ Albanian Institute of Sociology (AIS) \\ Email: Isokoli@hotmail.com
}

\section{Doi:10.5901/ajis.2014.v3n1p105}

\begin{abstract}
In the words of UN Secretary-General, Ban Ki-moon: "sustainable development is the imperative of the twenty-first century." At this point in the evolution of civilizations and societies, such statements have become de riguer for statesmen and social scientists alike; however, more often the discourse of "sustainable development" does not translate to concrete deeds. And in the case of Albania, even the discourse of sustainable development is lacking. In fact, the progress in Albania is measured almost exclusively through measures of GDP. However, using solely economic indicators, such as growth in GPD, to measure societal progress have been disputed since at least mid-twentieth century and continued to be disputed because such measures do not take into account "welfare indicators," such as the happiness and well-being of people within a society (see, e.g., Kennedy, 1968; Cameron, 2010). In this paper, is presented a new methodological approach to measuring sustainable development based on the happiness indices of Marks (2011) and Veenhoven $(1991,1995)$ and the measurement of the ecological footprint (Rees, 1992) of development projects. It is argued that this approach to measuring progress within societies is superior to merely economic approaches because it takes into account quality of life, environmental sustainability, and economic development. Such an integrative approach to measuring societal progress is particularly vital to sustainable development in countries such as Albania.
\end{abstract}

Keywords: sustainable development; change vs. progress; welfare indicators; well-being; HPI; ecological footprint; societal progress

\section{Considering Sustainable Development}

Let's begin with an example. On the day of the Tirana-Durres highway inauguration, two researchers - a sociologist and an economist - traveled from Tirana to Durres counting gas stations that were built on the old road and roughly calculated their costs. The result was astounding: on a road of $38 \mathrm{~km}$ there were 42 gas stations, some of which cost over one hundred thousand euro to build. They wrote an article with the significant title "Money for nothing!" (See, Sokoli \& Malaj, 2012). This phenomenon of entrepreneurial ventures overlap (according to the economic rule that "business limits the business") can be found everywhere.

This is a clear example of unsustainable development in that construction of a new highway between Tirana and Durres was inevitable and once the new highway became the primary mode of travel between the two cities, few, if any, of the gas stations on the old road would survive as viable investments. However, all of these "money for nothing" ventures were counted in Albania's GDP for the respective years they were in operation.

This example serves as a stunning illustration of why using economic measures of progress are inadequate and why attention to sustainable development and 'sustainability' must be taken into account to understand both the current conditions in a society and that society's prospects for progress in the future. In other words, 'sustainability' and 'sustainable development should be the main effort of all of today's generation, not merely because solely economic measured of progress may present a false picture of progress with a society, but perhaps more importantly because as sustainable development is inextricably linked to a free society.

If our approach to the financial, natural or social world is not based on the values of sustainability, future generations will not be able to live in freedom. Lack of stability limits us in all things, limits our potential to solve social problems. According to Jon Derbach - the author of the book, An agent for a sustainable America - sustainable development is one of the most important ideas to emerge during the twentieth century, along with the "promotion of democracy", "human rights protection", "free markets", "collective security" and the need to "fight poverty on a global scale." In addition, in referring to the new century, Ban Ki-moon, UN General Secretary, has said: "sustainable development is the imperative of the twenty-first century." 
But, what is sustainability and sustainable development? When we talk about environmental or ecological sustainability, the definition is quite clear, says Derbach (cit. Friedman, 2010: 58-59):

Something is environmentally or ecologically sustainable when [it] defends, restores or regenerates the environment, rather than degrades it. We can say the same for the world of finance: a market is financially sustainable when it encourages and adopts practices, instruments and innovations that promote long-term development of the economy, companies and jobs, instead of short-term thinking, which can reject all of these in one night.

Concomitantly, how are problems deemed to be "social problems"? One formal definition is as follows:

A social problem is a condition affecting a significant number of people, in ways considered undesirable, about which it is felt something can be done, though collective social action (Horton, Leslie \& Larson. 1997: 2-3).

This definition has four distinctive ideas: (1) a condition affecting a significant number of people; (2) in ways considered undesirable; (3) about which it is felt something can be done; (4) though collective social action. Based on this perspective the social problems of Albania are investigated through a national survey $(n=1364)$ and a certain hierarchy of social problems is fixed - regarding the public concern about certain issues (Sokoli \& Tershana 2009: 45-48). This research suggests, for example, that the social problems of present Albania go beyond the capacities of the society to resolve them (Sokoli, 2009). Two main conclusions can be derived from this perspective: the sustainable treatment of social problems (1) and certain priorities strictly based on the hierarchy of social problems (2).

We have suggested above what environmental or ecological sustainable development is. In principle, we can say the same principles for addressing sustainable development apply to addressing social problems: both require certain attitudes of societal members as well as a decision-making process that encourages movement, engages social forces, and encourages the practices, instruments and innovations that promote long-term solutions. But the treatment of social problems is integrated with attention to problems of economics, finance, ecology, politics, etc. They are affected as in a system of communicating vessels, operating on each other with an "invisible hand."

So, sustainable treatment of social problems is not only analogous to sustainable economic development; each complements and bolsters the other. In each case, sustainability cannot be measured only in size, but also in regard to the actions of institutions and individuals and what kind of relationships are built and maintained:. A significant difference exists between economic and social development built as a house of cards - with superficial relationships - and an enterprise built "brick by brick" with stable relationships with all stakeholders. So sustainability should be seen as a value. Being such, it is the opposite of thinking 'on the spot'. Instead, considered as a value, sustainability means to behave as if it would always be there, to give explanations, and to hold stakeholders responsible for whatever happens.

Acting under steady values cannot be reduced to a list of things to do. Sustainability has to do with mood, mindsets and behaviors that shape and perpetuate relationships, including those with family, friends, customers, investors, employees, lenders, fellow citizens, the community, the environment and nature. This means thinking and behaving in a way that the microcosm around you becomes stable (Friedman G., 2009).

Sustainability requires the establishment of a fair ratio between laws and values. Laws and rules show what you can do, and values show what you need to do. There is a difference between doing what you are doing right and doing what is right to do, in the long term.

\section{Considering GDP on Measuring Progress}

At this point in the evolution of civilizations and societies, proclamations about the importance of sustainable development have become de riguer for statesmen and social scientists alike; however, more often than not the discourse of "sustainable development" does not translate to concrete deeds. And in the case of Albania, even the discourse of sustainable development is lacking. In fact, progress in Albania is measured almost exclusively through measures of GDP.

While Albania's GDP has indeed grown continuously, at during the last decade, GDP is not the Alfa and Omega of progress. For one thing, the GDP of Albania is still very modest. For another, economists have estimated that even if Albania's GDP conitinues to grow at the current rate, the country it will take 50 years for the country to reach the average GPD of EU countries; and that assumes no growth whatsoever in the EU countries (see, e.g., Pellumbi, 2010). What's more, GDP growth is not an indicator of social progress, as the following formula shows:

$$
Y=C+I+G+(X-M)
$$


Where:

$Y$ - GDP per year

$\mathrm{C}$ - Private consumption;

I - gross investment;

G - Government spending;

$X$ - Export;

$M$ - Import.

Gross domestic product (GDP) refers to the market value of all officially recognized final goods and services produced within a country in a given period (normally in one year). GDP per capita is often considered an indicator of a country's standard of living.

But, the GDP framework cannot tell us whether final goods and services that were produced during a particular period of time are a reflection of real wealth expansion, or a reflection of capital consumption. For instance, if a government embarks on the building of a pyramid, which adds absolutely nothing to the well-being of individuals, the GDP framework will regard this as economic growth. In reality, however, the building of the pyramid will divert real funding from wealth-generating activities, thereby stifling the production of wealth.

John Perkins, in his book "Confessions of an economic hit man" (2006: 19), writes:

The growth of GDP may result even when it profits only one person, such as an individual who owns a utility company, and even if the majority of the population is burdened with debt. The rich get richer and the poor get poorer. Yet, from a statistician standpoint, this is recorded as economic progress.

As indicated by the formula and quote above, a strong argument can be made for the claim that GDP is a poor measure of social progress. GDP is not the indicator of the standard of living, is not the indicator of the well-being, so is not the indicator of sustainable development. Moreover, environmentalists for decades have argued that GDP is a poor measure of social progress, because it does not take into account harm to the environment.

The criticism of GDP assumption on measuring progress is not new. Economist Simon Kuznets was one of the architects of the US national account system, and one of the early proponents of the GDP/GNP, as a measuring system. However, in his report presented in 1934, he categorically stated: "The welfare of a nation can scarcely be inferred from a measurement on national income" (Cit, Marks, 2011).

More than three decades later, one politician started to question where this path of forever focusing on economic growth was leading us. In probably the most eloquent deconstruction of this measuring system, Robert Kennedy gave an impassioned speech at Kansas University in March 1968 at the beginning of his presidential campaign. He said:

Even if we act to erase material poverty, there is another greater task; it is to confront the poverty of satisfaction - purpose and dignity - that afflicts us all.

And after referring to a very high US GDP he continued:

... But the Gross National Product counts air pollution and cigarette advertising, the ambulance to clear our highways of carnage. It counts special locks for our doors and the jails for the people who break them. It counts the destruction of the redwood and the loss of our natural wonder in chaotic sprawl... Yet the Gross National Production does not allow for the health of our children, the quality of their education or the joy of their play. It does not include the beauty of our poetry or the strength of our marriages, the intelligence of our public debate or the integrity of our public officials. It measures neither our wit nor our courage, neither our wisdom nor our learning, neither our compassion nor our devotion to our country. It measures everything in short, except that which makes life worthwhile.

Kennedy's words still ring true. GDP simply does not measure what matters to everyday people struggling to live ordinary lives. GPD as the sole measure of progress has many shortcomings, perhaps the most important of which is that it is not an indicator of sustainable development.

\section{Beyond GDP as a Measure of Sustainable Development}

There are signs that things are starting to change. In January 2008, then French president, Nicolas Sarkozy, recruited three top economists of our time, Nobel Prize-winning economists Joseph Stiglitz and Amartya Sen, and the French economist Jean-Paul Fitoussi, to form together a special commission on the measurement of economic performance and 
social progress. This was considered the first call for new ways to measure progress (Marks, 2011: 138).

In February 2010, David Cameron, the British politician who has since become prime minister, quoted Robert Kennedy extensively and shared his vision of how Britain should start to measure GWB - General Well-Being. Cameron has announced plans that he is going to invest $£ 2$ million in creating the first national well-being indicators.

In the US, there has been a long tradition of social indicators work. In late 2010, the Rockefeller Foundation launched a new website called "The State of the USA." Its aim is to create a national dataset of key indicators of sustainable development, i.e. of key social, environmental and economic data. Recently there have also been calls to create national well-being indicators that go beyond GDP. These efforts have been led by three leading psychologists, Ed Diener and Martin Seligman (the authors of the influential paper - Beyond Money: Towards an economy of well-being") and Daniel Kahneman, who although a psychologist, is a Nobel Prize winner in economics.

The European Commission has held a series of conferences on "Beyond GDP" and its statistics agency, Eurostat, has started to work on developing well-being indicators for the European Union.

In addition, the OECD (Organization for Economic Co-operation and Development - effectively a group of wealthiest nations), has had a whole stream of high-level engagement work on "Measuring the Progress of Societies", i.e. on "Measuring Sustainable Well-being".

So the road of challenging the dominance of GDP to measure sustainable development is opened. The principle conclusion is that "...well-being needs to be put in the context of sustainability". However, it is also accepted that the measurement of well-being or happiness alone is complex, and coupling the measurement of sustainability with the measurement of well-being or happiness can be a dauntingly complex task. One way of tackling a more complex way of measuring the progress of nations that includes measuring the well-being or happiness in the context of sustainability, is the Happy Planet Index (HPI), launched for the first time in 2006, by NEF (New Economic Foundation, London). The HDI measures two things: the well-being of nations and the sustainability of nations.

The formula of $\mathrm{HPI}$ is:

$\mathrm{HPI}=\mathrm{Hly}: \mathrm{Efp}$

Where:

Hly - Happy life years

Efp - Ecological Footprint

So, HPI is the ratio of two components: "Happy life years" and "Ecological Footprint".

'Happy life years' was first development by Dutch sociologist Ruut Veenhoven. Its measuring combines subjective life satisfaction data with objective life expectancy data. The measurement has a powerful logic to it. It recognizes that a satisfactory life is not ideal if it is short; and that a long life is not ideal if it is miserable (Shah and Marks, 2004; Thompson et al., 2009; Michael et al. 2009).

The second element of HPI is measuring our impact on the planet. One of the best available approaches is considered the 'ecological footprint', developed by two ecologists, Mathis Wackernagel and William Rees.

The instrument of measuring the ecological footprint is a quiz of 26 questions. The Ecological Footprint Quiz (EFQ) estimates the area of land and ocean required to support our consumption of food, goods, services, housing, and energy including our wastes. The ecological footprint is expressed in "global hectares" (gha) or "global acres" (ga), which are standardized units that take into account the differences in biological productivity of various ecosystems impacted by consumption activities. The footprint is broken down into four consumption categories, which are: (1) carbon footprint (the area needed to absorb carbon emissions generated by your home energy use and transportation); (2) food footprint (includes the area needed to grow crops, fish, and graze animals and absorb carbon emissions from food processing); (3) housing footprint (which includes the area occupied by your home and the area needed to supply resources used in construction and household maintenance and transport) and (4) goods and services footprint. It is also broken down into four ecosystem types or biomes: cropland, pastureland, forestland, and marine fisheries.

Ecological footprint data can be easily obtained through various measures readily available (see, e.g., CSE, 2012) and the objective data needed for happy life years $(H L Y)$ calculations should be readily available through national statistics. While the subjective data needed for the HLY calculations may be more difficult to obtain, it is not impossible to obtain if government agencies, NGOs, and academic institutions collaborate to collect it. Moreover, as more nations start to monitor well-being progress, comparing happy nations and unhappy nations, or sustainable nations and non sustainable nations becomes a fairly easy task.

In this paper, we have argued for the need to see beyond GDP as the sole measure of progress for a nations, and argued for the adoption of a measurement of sustainable development based on a well- being Index. The time to change the direction in our everyday life, even in Albanian reality has come... 


\section{References}

Blewitt, John. 2008. Understanding Sustainable Development, London [etc.]: Earthscan.

Center for Sustainable Economy (CSE). 2012. "Ecological Footprint", available http://myfootprint.org/en/about_the_quiz /what it measures/ (available 10 September 2012);

Horton, Leslie \& Larson. 1997. The Socioology of social problems, New Jersey: Prentice-Hall Ltd.

Friedman, George. 2009. The next 100 years; a Forecast for the 21st Century, New York: Anchor Books.

Friedman, Tomas L. 2010. E nxehtë, e rrafshët dhe e mbipopulluar; Si është bota sot, si mund ta ndryshojmë atë?, Tiranë: Botimet IDK. Huppert F, Baylis N and Kaverne B (eds). 2005. The Science of Well-being. Oxford: Oxford University Press.

Marks, Nic. 2011. The Happiness Manifesto; How Nations and People can nature Well-being, London: New Economic Foundations (NEF).

Michael J, Abdullah S, Steuer N, Thompson S and Marks, N. 2009. National Account of Well-being: bringing real wealth onto the balance sheet. London: NEF

New Economic Foundation (NEF). 2009. Happy Planet Index, available www.happyplanetindex.org; (available 21 September 2012);

Perkins, John. 2006. Confessions of an Economic Hit Man, London [etc.]: Plume Publishing.

Pëllumbi, Servet. 2010. "Komunitarizmi dhe zëri i moralit"/Comunitarism and the voice of moral", Studime Sociale/Spcial Studies, Vol. 2, No. 2, pp. $15-25$.

Shah, H. And Marks, N. 2004. A well-being manifesto for a Flourishing Society, London: NEF

Shostak, Frank. 2012. "What is up with the GDP?", available: http://mises.org/daily/770/ (available 11 September).

Sokoli, Lekë \& Nora Malaj. 2012. Probleme sociale bashkëkohorre (Contemporaty Social Problems), Tiranë: Botimet Morava.

Sokoli, Lekë \& Elma Tershana. Varfëria dhe fëmijët në Shqipëri/ Poverty and Children in Albania, Tirana: Albanian Institute of Sociology \& 'Children Today' Center

Sokoli, Lekë. 2009. Some Present Social Problems of Albania, Tirana: Albanian Institute of Sociology.

Thompson S, Abdullah S, Marks N, Simms A and Steuer N. 2009. The (un)happy Planet Index; Why good lives don't have to cost the Earth, London: NEF. 
